\title{
1 \\ Payment in the history of healthcare
}

'The voluntary hospital system is not dead', declared one delegate at the 1938 annual conference of the Incorporated Association of Hospital Officers; 'It may be changing, it may eventually become something other than a voluntary hospital system, but it is not dead. ${ }^{1}$ Ten years later it would be brought to an abrupt end, nationalised and integrated almost wholesale into the new health service. While this was undoubtedly a significant change in the organisation of healthcare in modern Britain, how to understand that change is open to debate. Historians and social scientists have variously understood the NHS as both a rejection and a culmination of what came before. These different narratives cast patient payment in contrasting roles. It was either an important indicator that the voluntary hospitals had effectively become private hospitals ahead of their nationalisation, or it was a major plank in the establishment of a more democratic form of health provision that prefigured a socialised health service. Thus, to appreciate the place of payment within the pre-NHS hospital system, it is important to understand the wider picture within which it emerged.

Payment becoming a standard feature of the hospital experience was not, however, an exclusively British phenomenon. After surveying some key themes in the historiography of healthcare in early twentiethcentury Britain, this chapter will turn to a few enlightening international comparisons. Previous international perspectives on hospital funding have tended to focus on health insurance, which allows for some revealing comparisons. For example, under the National Health Insurance scheme British doctors were paid according to a rather ungenerous capitation fee, while the German system it was based upon had allowed the doctors to set their own fee for their service. ${ }^{2}$ Equally, 
the French insurance system allowed patients the right to choose their doctor, whereas previously 'the so-called non-paying sick had had no such right because free medicine had been a charitable exchange." Neither British doctors nor patients were similarly empowered by state insurance and this comparison provides useful context for the patient payment schemes in Britain that likewise did little to empower either. In contextualising the British payment schemes we will focus on comparisons with the United States, France and Ireland. Each had a different experience of introducing patient payments. The American 'private patient revolution', the adoption of social insurance programmes in France and the distorting influence of the Irish Hospitals Sweepstake all contrasted sharply with the British experience. ${ }^{4}$ At the same time, however, they each show the same fundamental changes to the technological capacities, social function and patient base of the hospital in the early twentieth century. Internationally and domestically, it is within this broader context, as one change at a time of many, that we can best understand the arrival of patient payments as normal practice within the British hospital in the decades preceding the inception of the NHS.

\section{The road to 1948 ?}

The establishment of a national health service was a key plank of Labour's postwar social reforms. At the end of the Second World War, business as usual was restored to British politics in a startlingly prompt manner. Only two weeks after the Allied victory in Europe, Churchill's national coalition partners withdrew their support and forced the first general election for a decade, and the first on traditional party lines since before the Wall Street Crash. ${ }^{5}$ When Labour won a shock landslide victory, and the modest Clement Attlee took Churchill's place as Prime Minister even as fighting continued in the Pacific, some aspects of the new government's policy were characterised by continuity. The primacy of the Anglo-American alliance is the most obvious, but the wartime coalition had also been keen to follow the 1942 Beveridge Report in exploring the options for postwar social reconstruction. Beyond this, however, Labour's first majority government took Britain in a radical new direction. ${ }^{6}$ Much of the empire was dismantled at an alarming pace while key industries including coal, 
steel, electricity and the railways were brought under state control. ${ }^{7}$ Almost as an extension of this programme, Britain's entire hospital sector was nationalised. However, the creation of the NHS is usually seen as totemic not of Labour's nationalisation policies, but of its wider establishment of the welfare state. ${ }^{8}$ While reforms to social security and pensions have little place in the popular memory of the 1945 Labour government, the NHS is often referred to interchangeably with the welfare state itself.

The hallmarks of this new health service were that it should be universal, comprehensive and free at the point of use. The funding for this came almost entirely from general taxation, breaking what link there was between paying for and receiving care in times of sickness. This was delivered by a tripartite system: regional boards for the newly nationalised hospitals, primary care services provided by self-employed professionals contracted to treat NHS patients (including dentists, opticians, pharmacists and general practitioners serving as gatekeepers to many other services), and local authority Medical Officers of Health overseeing the remaining public health and social care services (such as community clinics, health visitors for expectant and new mothers, school medical services and immunisation programmes). ${ }^{9}$ Despite almost continual reform, this fundamental structure of the NHS has so far survived for many decades. There is, therefore, no escaping the significance of the 'appointed day', 5 July 1948, when this new health service came into being, three years to the day from Labour's surprise election victory.

For our purposes, we might see 1948 as the abolition of payment. Yet this clear-cut account needs nuancing for both before and after the introduction of the NHS. While questions of payment were removed from the doctor-patient relationship, it was only a few years before the very occasional payments for additional items were joined by standard charges for the services of opticians and dentists and then for all prescriptions. Meanwhile, the separation of private beds continued. Where before private beds had been the sole provision made for the middle classes, they were now able to enter the free public wards and amenity and pay beds became options for purchasing a greater degree of privacy or the services of a private doctor or surgeon. Indeed, the choice between free or fee-paying services meant the middle-class patient had more choice under the NHS than before. 


\section{Rejection or culmination?}

With the transition from a diverse patchwork of providers to a comprehensive and universal service as the dominant teleological narrative in the history of British healthcare, change looms large. Yet there is no consensus on the cause, or even the chronological scope, of that change. Debate rages over whether the establishment of the NHS amounted to a rejection or a culmination of the developments of preceding years and decades. If and how payment is recognised as part of what came before makes a difference here.

The NHS itself, for its official historian Charles Webster, seems almost a fluke of history. ${ }^{10}$ Aneurin Bevan, unexpectedly appointed Health Minister by Attlee, conducted what he calls an 'audacious campaign' crucial in determining the specific settlement brought about. ${ }^{11}$ This gave greater prominence to central government than Labour's previous plans for a municipal-run health service, crafted in no small part by the Socialist Medical Association and championed around the cabinet table by Ernest Bevin. ${ }^{12}$ While this accounts for the particular organisational form of the NHS, there is a good case that any minister from any party would have introduced a health service of some description. Indeed, to those involved with Bristol's voluntary hospitals, proposals put forward by Henry Willink, the Conservative health minister in Churchill's wartime coalition government, amounted to 'promises of free services for all when needed', which they feared would act as a disincentive to charitable support. ${ }^{13}$ Whether Bevan is given the credit personally or not the narrative here is essentially one in which the NHS is ultimately a rejection of, in the familiar left-wing rallying cry, the bad old days of the 1930s - a refrain Bevan himself used in his famous speech describing those Conservatives he held responsible for the poverty he saw in his younger days as 'lower than vermin'; a speech given on the eve of the inception of the NHS. The complex realities of payment schemes are ignored in this narrative. Instead, payment exists as a symbol of free-market healthcare of a kind that in fact never existed on any significant scale. A more nuanced understanding of the place of payment in British hospitals before and after 1948 adds to a growing appreciation that it was the high-point in a longer period of kaleidoscopic change.

An alternative narrative has been increasingly favoured by historians, mostly since the turn of the century, whereby the new settlement of 
1948 combated the serious shortcomings of earlier years less by overturning all that had come before and more by universalising pioneering local initiatives. The wartime Emergency Medical Service has always been held up as an example of what could be achieved by a planned health service, prompting the British people to seek a more ambitious health policy, ${ }^{14}$ but historians and social scientists have also started looking further back to find the developments of the interwar years bringing about some degree of co-ordination and integration. ${ }^{15}$ While there were certainly pioneering municipal initiatives prefiguring the NHS, including the London County Council, ${ }^{16}$ it is unclear how much the shift from poor law to municipal hospital provision actually led to any change on the ground. ${ }^{17}$ Equally, historians have recently become increasingly aware of the voluntary provision of healthcare, and welfare more broadly, as part of a wider rediscovery of civil society in Britain's past. Moving beyond a whiggish view of increasing state intervention as an inevitable journey towards a better society, what Pat Thane has called 'the ruling paradigm of welfare state histories in the optimistic 1950 s and 1960s, ${ }^{18}$ has revealed a more significant role for voluntary hospitals and other voluntary organisations in interwar projects than might be assumed if progress is viewed simply as ever-greater state intervention on a march towards socialised medicine. ${ }^{19}$

This is one way in which it has been helpful for historians to distinguish between progress made and steps taken towards the NHS specifically. 'By looking at everything through the prism of the NHS' and measuring other systems constantly 'against the gold standard of some imagined NHS', Barry Doyle has warned, the risk is 'we overlook how far provision had travelled in the 20 years after 1918 and how much potential it had to continue to grow. ${ }^{20}$ Indeed, there were a number of viable alternatives to the specific form the NHS took. There is no need to make a judgement over whether any of these might have been preferable, but it is hard to truly understand the history of British healthcare without acknowledging that they existed. Some of these would have also provided medical care free at the point of use, whether under another model of public provision, with a mixed economy approach, or through the adoption of social insurance as a development of the hospital contributory schemes. Once we recognise the various options that were available and that some of them were already being implemented between the wars, what becomes clear is that any 
clear-cut distinction between before and after 1948 is likely to be an oversimplification.

This is true in the case of payment. While the interwar period's fledgling municipal hospital services anticipated the NHS in other ways, they also operated effectively the same payment system as the voluntary hospitals. Legislation in 1879 and 1885 had already empowered poor law guardians to recover 'the cost of maintenance' from those who were deemed able to contribute, although such contributions were minimal - amounting to only 1 per cent of income at the Whitechapel Workhouse in London. ${ }^{21}$ The 1929 Local Government Act, passed by Health Minister Neville Chamberlain, both allowed local authorities to appropriate workhouse infirmaries as general hospitals for the community as a whole and required them to recoup whatever costs they could from their patients. As such, the interwar years offer a previously overlooked example of payment within a mix of public and voluntary hospitals as one of the roads not travelled. Just as there were no fixed or absolute boundaries between the various sectors of the mixed economy of healthcare, as Paul Weindling has noted taking a global view, the British pre-NHS situation demonstrates the practice of paying the hospital did not belong solely to one sector. ${ }^{22}$ Payment may have been more common in the voluntary hospitals and it may therefore have prompted more fundamental questions of its traditional character, but it operated across the pre-NHS mixed economy of healthcare.

\section{Hospital planning and funding: a local perspective}

The approach taken here to investigate these payment schemes is to use, as a starting point for the analysis, the city of Bristol as a local case study. There are two possible reasons to adopt a local case study approach. First, to test out established patterns or explanations in a new locality. Second, to consider the local dimension of the issue under investigation when it is important to understand it fully. Our rationale is the latter. Indeed, the city has not been overlooked in the literature of pre-NHS healthcare. Martin Gorsky has assessed the city's 'haphazard journey towards an integrated hospital system' in the late 1930s, following 'several false starts' and disputes. ${ }^{23}$ In general this was undoubtedly the case, with developments usually not co-ordinated between hospitals or sectors. Yet when it comes to the introduction and 
administration of hospital payment schemes, either in concert or in parallel, we find a perhaps surprising amount of uniformity between institutions, voluntary and municipal.

Indeed, the speed with which a common model of payment fell into place across British hospitals in the years following the First World War is noteworthy, not least because more generally this was a period in which a common model of hospital organisation was only established during the late 1930s. This is not to say that no earlier progress was made towards integrating local hospital services or that there were no previous pioneering efforts. Gorsky's work on Bristol is characteristic of a wider body of work, consisting in no small part of a substantial collection of local case studies, where a number of historians have sought to reassess the state organisation of pre-NHS healthcare. In his study of Manchester, John Pickstone suggested by the mid-1930s a local committee was doing much of the work that would later be done by the NHS Regional Hospital Board. ${ }^{24}$ This was a notably more positive account than that offered by Richard Titmuss. Looking back in the first years of the NHS, he saw the problem not only as being that the voluntary and public hospital systems were so diverse, with differences between the two as well as within the 'multiplicity of individualistic voluntary hospitals' ranging from 'great teaching hospitals' to 'small, debt-ridden institutions', but also that they 'had grown up without a plan. ${ }^{25}$ While Pickstone was less damning, he also cautioned that in this respect Manchester was exceptional.

Perhaps inevitably there has been a focus on the pioneering exception. David Hamilton has characterised the Highlands and Islands Medical Service, established as early as 1912 and integrating general practitioners with other health and welfare institutions and services, as anticipating the NHS both 'by removing the cash nexus between the patient and doctor and by the comprehensiveness of its aims. ${ }^{26}$ The Bradford Municipal Hospital initiative of 1920 also serves as a good reminder that the earliest initiatives were not those of the capital. ${ }^{27} \mathrm{By}$ the 1930s, however, the London County Council was the largest single provider of hospital beds in Britain, and for some it offered a model of how local government might form the bedrock of future hospital reorganisation. ${ }^{28}$ Indeed, one contemporary report noted that the area in and around the capital was a rarity for the 'comprehensive general public hospitals service' in development. ${ }^{29}$ 
Alongside these local initiatives were others under the leadership of the local Medical Officer of Health, to which Gorsky has drawn attention. One such scheme was the 'Aberdeen experiment', which he has described as a 'trail blazer' for its advanced medical-governmentalacademic network. ${ }^{30}$ Yet another example would be the ill-fated Gloucestershire scheme, covering Bristol. The scheme planned for a referral network of public and voluntary hospitals, health centre 'outstations' and contracted private GPs, all under the direction of the Medical Officer of Health. It proved too ambitious a scheme in an era of financial retrenchment in the mid-1920s and 1930s. ${ }^{31}$ If public spending likewise meant that developments in the municipal field were subject to notable local variation, ${ }^{32}$ Barry Doyle offered a positive account of the integration of public and voluntary hospital services in the northern industrial cities. While the story was not always one of the forward march of progress, he has found developments based on collaboration rather than competition from the 1920s to the 1940s bringing about integrated and rationalised hospital services in Middlesbrough, Leeds and Sheffield. ${ }^{33}$

These local case studies have done much to nuance the verdict on how successful or otherwise the pre-NHS hospital services were. They have slowly tilted the balance of opinion away from Charles Webster's view that competition rather than consensus drove what improvements were seen in the interwar years. ${ }^{34}$ We might expect to find hospitals taking payment from patients bringing them into direct competition, yet, as the following chapters show, this was not typically what happened. On some occasions supposedly competing hospitals collaborated on the introduction of payment schemes, while on others a sense of rivalry may have led institutions to imitate such arrangements, but there is no evidence of outright competition for customers between local hospitals.

\section{Hospital finance}

One important strand within this historiography has been a focus on hospital funding. The history of the voluntary hospital system is itself, inevitably, bound up with funding. It was the emergence of a mass, industrial, increasingly urbanised society that brought about the conditions for its foundation. These were the capacity, demand and opportunity to tap the collective financial resources of the community through 
the investment of the wealthy. This drew upon an 'underlying ideology' Roy Porter saw behind the eighteenth-century hospitals, finding in their establishment an 'act of conspicuous, self-congratulatory, stagemanaged noblesse oblige' evident in the wider Georgian moral economy. ${ }^{35}$ It was through alliances of medical men, seeking to advantage their own professional standing and that of their given specialism, and their wealthy supporters that a second wave of voluntary hospitals was established in the nineteenth century. ${ }^{36}$ Meanwhile, financial backing also came from local businessmen who saw advantages in the voluntary hospitals keeping their workforce patched up and treated in cases of acute disease. ${ }^{37}$ Around the turn of the twentieth century, there was a diversification in voluntary hospital income, with new systems of contributory funding and patient payments being introduced. $^{38}$ In London's voluntary hospitals, Keir Waddington found declining income from invested income especially important for prompting the establishment of Hospital Saturday and Sunday collection funds towards the end of the nineteenth century. ${ }^{39}$ At the same time in Birmingham, Jonathan Reinarz has suggested a democratisation of funding was seen with the growing importance of businesses and mass funding schemes. ${ }^{40}$

However, as the analysis by Martin Gorsky, John Mohan and Martin Powell suggests, it was not until the 1930s that philanthropy went from being 'a junior partner in the funding mix' into outright decline, and by the end of the decade patient payments were providing over oneeighth of voluntary hospital income. ${ }^{41}$ They tentatively pose the explanation that the call for donations was undermined by the growth of hospital contributory schemes on one hand, and increased taxation to fund an expanding public hospital service on the other. Certainly this was a time of great change for public hospitals in terms of their governance, technical capacity, the range of services they offered and the demand for those services, as well as expenditure devoted to them. Alongside central and local state commitments to spending on public health, maternity and child welfare and poor law facilities, hospitals were becoming an important item in spending on municipal services. ${ }^{42}$ Where public hospital services had been previously provided for sections of the community - paupers in the workhouse or sanatoria for infectious disease patients, for example - there was a move towards municipal hospital provision for the whole community. ${ }^{43}$ Spending on 
this project exhibited marked variation depending on locality and the nature of local politics. ${ }^{44}$ Yet one aspect of this complex picture that has gone almost entirely overlooked is the place of patient payments within the public hospitals' own funding mix, an issue to which we will return. Moreover, it is likely these changes in the growth of a public, tax-funded hospital system would have damaged calls for charitable donations to replicate many of their services. It would certainly be in keeping with the wider withdrawal of the middle classes from 'associational voluntarism' that Martin Daunton has suggested took place in the early twentieth century, resulting in a decline in 'the significance of philanthropic welfare' as 'a central element in the stabilization of urban society. ${ }^{45}$ On this basis it makes sense to equate funding success for the voluntary hospitals in this period with a move away from traditional philanthropic sources of income, as Steven Cherry has done. ${ }^{46}$

Recent work, however, has been less damning of hospital fundraising in the interwar years, not least Nick Hayes and Barry Doyle's examination of the finances of large voluntary hospitals in Leeds, Leicester, Nottingham and Sheffield. Where others have linked a democratisation of hospital governance to a move away from philanthropic funding, they see some of this democratisation taking place within the charitable support of hospitals. They note that fundraising became 'less dependent on elite contributions and much more located in those processes and activities where all members of society were encouraged to contribute time and money to generate common public resources. ${ }^{, 47}$ Central to this new, more democratic hospital fundraising was the public donation of gifts in kind, such as food or bedding, which significantly reduced the running costs of the hospitals. ${ }^{48}$ Equally they have afforded greater prominence to the place of payment in their local case studies. For example, Doyle has suggested that what appear as substantial changes to the funding mix in voluntary hospital account books might actually mask greater continuities in charitable income and purpose. In particular, he notes that the growing revenue under the heading of patient payments in Leeds and of contributory schemes in Sheffield saw long-standing income simply relabelled. ${ }^{49}$ Meanwhile, Hayes has highlighted the resistance to introducing new forms of patient payment in 1930s Nottingham. This included the forced resignation of the President of the Nottingham General Hospital, where replicating the middle-class private wards of the city's Eye Infirmary was amongst 
the unpopular changes he proposed..$^{50}$ As such, weaving considerations of patient payments into the financial and political analysis of local hospital histories is now the norm. We now need to take one step further and place patient payments centre stage.

In bringing the issue of patient payments more fully into this ongoing debate, it is essential to adopt a local approach, as decisions about the various systems and schemes of payment introduced were acutely local. There was no national mechanism for introducing a new hospital policy. Even after Lloyd George's coalition government established the Ministry of Health in 1919, there was no direct control over even the nation's public hospitals. The Ministry's limited influence was exerted a decade later when the Local Government Act made recovering what costs it could in payments from patients a condition of municipal appropriation of poor law workhouse infirmaries. ${ }^{51}$ Yet it was a matter for the local health committee whether they wanted to opt for appropriation (only around half had done so another decade later) and then their responsibility to decide how and how strictly to implement patient payments. For the voluntary hospitals such decisions were entirely institutional ones. It is therefore vital to understand the institutional and local dynamics at play. At the same time, neither the issues faced nor the new approaches adopted were specific to any one locality. Thus we must place the local within its wider context.

The social role of the hospital: an international perspective

In response to these debates, a more nuanced analysis has developed around what types of funding continued or declined, a crucial aspect of the wider reassessment of the success or failure of the organisation and development of hospital services before the NHS. Our concern here, however, is not principally to contribute to this ongoing task, important though that is. Instead, our focus is on using those new mechanisms of funding to gain a better understanding of the changing character of British healthcare during this period. The question of whether a hospital could remain a charity whilst taking payments from patients, the recipients of that charity, is hard to separate from a wider historiographical debate in the social histories of medicine in Britain, Europe and North America, on whether the hospital had by now lost its social function. ${ }^{52}$ 
By the twentieth century, the very nature of the hospital was changing. Founded as religious refuges for the sick, they became modern centres of research and treatment as care gave way to cure. ${ }^{53}$ The late nineteenth and early twentieth centuries were important years in a longer period of change, seen by Paul Starr as the moment of the hospital's 'scientific redemption. ${ }^{54}$ One consequence of this transition was that the traditional 'patient narrative' was lost in the medicalisation of the hospital, with the patient supposedly 'de-personalised' within the institution. ${ }^{55}$ Moreover, the patient profile changed at the turn of the twentieth century, 'as rising faith in biomedicine, post-Pasteur, coupled with technological transformation made hospital admission attractive to the middle classes. ${ }^{56}$ Hilary Marland has rightly noted that, despite these changes, a 'multi-functionalism' combining the medical and welfare roles of the hospital survived into the twenty-first century. ${ }^{57} \mathrm{To}$ appreciate the extent to which the social role of the hospital has been maintained in Britain, it is important to recognise the uncoupling of decisions about admission from those concerning the terms of admission. The former became exclusively a medical matter while the latter continued to be mediated, mostly intimately by the almoner. This uncoupling also limited the impact of insurance and commercial arrangements on the patient contract. The contributory scheme voucher arrangements, Steven Cherry has suggested, brought about a 'quasiinsurance' system, radically different from the deferential philanthropic traditions of the voluntary hospitals, and effected the terms of admission but not admission itself. ${ }^{58}$ In this way, admission was opened up while philanthropy was maintained in the relationship between the voluntary hospital and the patient.

\section{Payment in American hospitals}

This is a strikingly different account of the changes taking place in British hospitals to those historians have given for the hospitals of the United States of America, where many of the hospitals had been founded explicitly on the same lines as those in Britain. The largest of American hospitals were the municipal and county public hospitals relying on state funds and primarily treating the poor. While the elite voluntary hospitals were prestigious medical centres providing acute care, smaller religious and ethnic hospitals were less likely to be endowed and more likely to rely on patient fees. The smallest were the 
proprietary hospitals that served as private surgical centres for the middle and upper classes. ${ }^{59}$ Across these institutions, fundamentally, the same categories of patient existed as in Britain, yet the change in the balance between them occurred at a speed and on a scale far greater than in the British case. As the twentieth century began, 'a new factor emerged, a vigorous crop of private and proprietary hospitals that competed for fee-paying patients with unabashed and unambiguous enthusiasm'. This, according to Charles Rosenberg, amounted to a 'private patient revolution' in the first two decades of the century. ${ }^{60}$ This was not limited to any one part of the United States. For example, one voluntary hospital in Illinois was already evenly split between free and private patients in 1904, with four-fifths private by $1911 .{ }^{61}$ Meanwhile, the oldest public hospital in Texas - founded in 1883 for 'only those citizens who could not afford the services of a private Doctor and hospitalization' - admitted private patients from 1915. They were consistently the majority of patients throughout the 1920s and 1930s, and by the 1950s represented over 60 per cent of patients. ${ }^{62}$ Despite gradual growth up until their nationalisation in 1948, barely more than a dozen hospitals in all of Britain would have had such a high proportion of private patients. As Starr notes, since private rooms were usually for private patients the shift to private provision as the primary work of the American hospital was evident from changing architecture. 'General hospitals built before 1880 consisted almost entirely of wards, with only a few private rooms', whereas 'by 1908 large wards had declined to only twenty-eight percent of the beds in hospitals' and 'single rooms now accounted for nearly 40 percent. ${ }^{63}$ Meanwhile, in stark contrast to Britain, 'more proprietary than charitable hospitals were being built' in America at the beginning of the twentieth century. ${ }^{64}$

Starr explains the adoption of patient payments in terms of financial necessity, a direct response to the failure of donations and bequests to cover costs. ${ }^{65}$ The dramatic rise of private patients in particular, however, he puts down primarily to the growth of surgical work, which 'provided the basis for expansion and profit in hospital care. ${ }^{66}$ Rosenberg has meanwhile pointed to a wider sets of factors: 'Hospital budgets, physicians' practice patterns, attitudes towards science, charity, and the prerogatives of class - as well as the $\mathrm{x}$-ray, antiseptic surgery, and clinical laboratories - interacted to transform the early twentieth-century American hospital. ${ }^{67}$ Taking into consideration the broader range of factors identified in studies of US hospital finance helps to explain the 
difference with the British hospitals, which had the same core changes in hospital medicine to manage. Consequently some similarities can be seen; for example in the concerns about 'abuse' David Rosner has identified in New York, the response to which was a system of public grants that focused provision of independent charity hospitals on 'truly indigent clients' in the 1900s. This was a system that encouraged 'administrators to pay close attention to the payment capabilities of patients, to initiate means tests, and to differentiate services according to class'; and one which was policed by public inspectors charged with 'investigating doubtful cases', who we might understand as municipal almoners. ${ }^{68}$ Even with this system, however, 24 per cent of patients in New York hospitals were private by $1921 .{ }^{69}$ The American example is one of private medicine embraced by the hospitals, with an effect on their character. 'The rise of hospitals', Starr tells us, 'offers a study in the penetration of the market into the ideology and social relations of a precapitalist institution. ${ }^{\text {,70 }}$ Rosenberg likewise sees a 'fundamental shift in social function and world view' in the American hospitals. ${ }^{71}$ The same has been charged of their British counterparts, yet with far less supporting evidence.

\section{Payment in French hospitals}

A different contrast can be seen from the French experience. France, like Britain and many other European countries, undertook wideranging health and social reforms after 1945, and as a consequence the interwar years are often dismissed by historians as merely a prelude. ${ }^{72}$ Yet French healthcare in the period 1870 to 1940 has been described by Jean-Paul Domin as 'extensive. ${ }^{73}$ Over this period, numerous French cities constructed what Timothy B. Smith has termed local 'miniwelfare states', most notably Lyon and Paris, where the hospitals were transformed 'from refuges for the poor to medical establishments intent on catering for all but the wealthy' as part of an agenda to 'modernize and democratize. ${ }^{, 74}$ The means by which this was done was not through an American-style move to private medicine or a British-style diversification within a mixed economy, but primarily by turning to the state. The French system of hopital and hospice allowed for a distinction between curable and incurable patients, similar to the patient base of voluntary and public hospitals in Britain, but both received central and local state funding and state direction to a far greater degree - and were consequently 'very clearly public institutions' in a way their British counterparts were not. ${ }^{75}$ This was developed during interwar years, a 
time of 'quiet yet bustling reform at the local level' for French health and social services. ${ }^{76}$ Local activity was combined with central reform in 1928 when legislation made mutual health insurance compulsory for one-third of the population. ${ }^{77}$ Coverage began in 1930 and increased numerous times over the following decade, taking the proportion of the French population with health insurance from 6 per cent to a majority, and bringing a far greater degree of unity to the French healthcare system than the British. ${ }^{78}$

The system adopted in France was a different approach to tackling the same dilemma. With 1920s social insurance debates asking who should foot the bill for meeting the costs of medical inflation and bringing hospital medicine to the middle classes, there was a sense that the burden had fallen once again on 'the economic victims of the war': the new poor of smallholders, fixed-income pensioners and respectable but low-wage workers. ${ }^{79}$ To cater for those not covered by assistance programmes, hospitals in Rouen developed a sliding scale system, where paying patients were admitted with charges between Fr5 and Fr 15 depending on their circumstances. ${ }^{80}$ That there was any demand for such a policy was a far cry from the situation 'prior to the interwar years' when 'a middle-class family would never have dreamt of sending an ill family member to the hospital." 'Hospitalization became a middleclass survival strategy' and lost its shame, Smith has suggested, seeing the cause as principally economic rather than due to advances in medical technology. ${ }^{82}$ His overarching narrative is one of charitable institutions struggling financially and turning to the local state, who in turn looked to the central state, yet he also notes that in the 1930s financial need forced hospital bureaucrats to seek out private patients. ${ }^{83}$ Barry Doyle has gone some way to uncover the wider history of private hospital provision in France. He found that France, like the United States and Britain, developed private provision in its public and charitable hospitals in the late nineteenth century. Unlike Britain, however, pay blocks in hospitals and smaller mutual surgical centres became common features of medical care in French cities before the First World War. $^{84}$

\section{Payment in Irish hospitals}

One nation sometimes assumed to have embraced commercial hospital medicine more readily than Britain is Ireland. This is an important 
assumption to test, not least since Ireland only broke away from the United Kingdom to form the Irish Free State in 1922. As closely entwined as they were, Henry Burdett saw a difference in their hospital systems. In 1879, he claimed Dublin had 'done more to give the pay system a trial than any other town in the United Kingdom. ${ }^{85}$ Differences in relation to patient payment might then be simply regarded as one of a number of differences between British and Irish hospitals. For example, in Ireland the term 'voluntary hospital' typically referred to Protestant institutions, where Catholic voluntary hospitals might be known as 'religious hospitals'. They also operated alongside prominent public general hospitals, in the form of County Infirmaries, earlier than equivalent developments took place in Britain. ${ }^{86}$

Yet the differences in terms of patient payments come down primarily to the effects of a peculiar interwar episode of state intervention in Dublin. Across the rest of Ireland local variation falls well within the range seen between towns and cities across Britain. Contributory schemes were a significant factor in Belfast, in the northern area of Ireland that remained part of the United Kingdom, and which looked much like any major British city in this respect. ${ }^{87}$ Meanwhile, the proportion of voluntary hospital beds for private middle-class patients across Ireland was only around 5 per cent in the 1930s, lower than that in Britain, catching up only as their paths diverged dramatically when Britain was readying to establish its National Health Service. ${ }^{88}$ In 1936 the Irish Hospitals Commission described increased accommodation in General hospitals for that section of the community in a position to pay for it' as 'a development of comparatively recent times. ${ }^{89}$ The Bon Secours, a Catholic religious order, established a 105-bed private hospital in Cork in 1915 and another in Tralee in 1921. Some of the larger general voluntary hospitals in Dublin had opened private homes by the early 1920s, including a 100-bed development at St Vincent's and a smaller establishment at the Mater Hospital. ${ }^{90}$ The Mercy Hospital in Cork had also established a private wing by the early 1930s. Prior to independence the Irish Catholic voluntary hospitals received no local authority funding, nor the Anglo-Irish charitable donations from which Protestant hospitals benefited. This was a significant factor in their nursing congregations becoming 'unlikely entrepreneurs' and catering for middle-class patients able to pay full medical fees and increasingly turning to hospitals for the most advanced medical care. ${ }^{91}$ 
The most notable factor, however, was the remoulding of the private hospital sector in Dublin in the 1930s, following the establishment of the Irish Hospitals Sweepstake. ${ }^{92}$ This novel approach to fundraising, with tickets randomly assigned to horses in major races bought across Ireland and internationally, was a direct response to the financial difficulties of the Dublin voluntary hospitals. The responsibility for distributing the large sums raised fell to the new Irish Hospitals Commission, which soon found that in setting the criteria for eligibility to receive those funds it had an important new means by which the state could direct the development of the capital's hospitals. The 'guiding rules' they laid down made the balance between patients paying at different rates a condition of receiving sweepstake funds. This required 25 per cent of beds to be reserved for free patients and 20 per cent for those private patients who could afford to pay above the cost of their treatment and maintenance, leaving 55 per cent for those paying the cost of treatment and maintenance either in full or part. Meanwhile, the Commission stated in their first report that these guidelines should not be implemented too rigidly 'as to cause an implication that the provision, promptly, of facilities for all those who are unable to pay is not the overriding obligation. ${ }^{93}$ This was clearly an attempt to protect hospital provision for the poorest.

However, there appears to have been a problematic gap between voluntary hospital practices (the same in Ireland as in Britain in this respect) and the understanding of them underpinning the guidelines drawn up by Hospitals Commission. They defined 'free patients' as 'patients paying 10s. per week or less. ${ }^{, 4}$ Since it was not uncommon to find 25 per cent of patients being admitted entirely free, the guidelines actually allowed for a substantial increase in working-class payment. Meanwhile, the proportion of beds they said were to be set aside for private patients was five times higher than the rate across Ireland at the time. ${ }^{95}$ While the specific mix of income from different levels of patient payment varied widely between the city's voluntary hospitals, the Hospital Commission's eligibility criteria unintentionally opened the door to a far greater scale of middle-class private treatment in Ireland's hospitals than had previously been the case. ${ }^{96}$ This was perhaps the biggest contrast with the British voluntary hospitals, for whom slower and smaller changes were at the time, and have since been, grounds for seeing them as private hospitals in all but name. 


\section{Charity and citizenship}

The criticism that voluntary hospitals, once taking payment from patients, had essentially become private hospitals should be understood as one episode in their longer history, in the writing of which their 'voluntary' nature has been a greater and lesser focus at different times. This was prominent in a wave of works examining the eighteenth- and nineteenth-century hospital as a site for the formation of middle-class identity. ${ }^{97}$ To a lesser degree, the voluntary nature of the hospital was also significant for scholars asking what it meant to the poor of these centuries to be recipients of medical charity. ${ }^{98}$ By the twentieth century, however, there is little place for such matters. The lack of attention paid to the meanings of class and charity in the literature implies an assumption that the charitable nature of the voluntary hospital was either undermined or entirely ended as it evolved 'from an institution reliant on the charity of the rich on behalf of the needy, to a service funded principally by its users. ${ }^{99}$ The increasing presence of private patients was described critically by Brian Abel-Smith as mixing 'trade with charity' and by John Pickstone as 'commercial medicine ... invading the hospital field. ${ }^{100}$ While others have challenged this depiction on the grounds that old sources of income were of continuing importance, we also need to question whether the difference between old and new sources of income really does amount to an end of philanthropy as the organising principle of the hospital. ${ }^{101}$

Central to this is the relationship between the institution and the patient. A philanthropic relationship does not, of course, depend solely upon the transfer of funds, nor does it carry any requirement for kindness. As Alan Kidd has noted, echoing the anthropological work of Marcel Mauss on The Gift, its hallmark is the use of imagined reciprocity (usually incapable of being enacted) to demonstrate and reinforce social hierarchies. ${ }^{102}$ That philanthropy is defined by the donor and the volunteer, who decide the timing, scale, method and object of charity, is fundamental to this power relationship. By contrast, the passive recipient is afforded little scope for personal agency. This was summed up by Fernand Braudel as 'He who gives, dominates. ${ }^{103}$ Indeed, this view of the passive recipient of charity has much in common with the notion of the patient as a disempowered subject of what Foucault termed the 'medical gaze. ${ }^{104}$ Yet historians looking at the hospitals of the early 
twentieth century have tended not to see patients as defined by their powerlessness.

The interwar years saw a new consensus emerge, Gorsky has suggested, around 'the conception of hospital care as a right of citizenship. ${ }^{105}$ This would appear to foreshadow the thinking of sociologists such as T.H. Marshall and Richard Titmuss who looked to the welfare state to bring about the solidarity of a new communal citizenship based on 'class fusion'. While the NHS moved Britain's healthcare a long way towards this, it is hard to see the pre-NHS hospitals as embodying anything close to this social democratic collectivist ideal. Such a case could, however, be made for the voluntary hospitals' partners in the voluntary sector. The contributory schemes and medical aid societies certainly had stronger strands of the collectivist impulse than the hospitals. For example, Steven Thompson has described how in early twentieth-century South Wales medical aid societies attempted to provide 'comprehensive public services. ${ }^{106}$ Doyle has instead characterised interwar contributory schemes as an arena in which access and entitlement could be negotiated, as a means of ensuring what it was felt should have been guaranteed by right. ${ }^{107}$ However, turning our focus to payment in the hospitals themselves encourages a view whereby the notions of citizenship embodied were not those of a passive recipient of welfare rights, let alone an empowered consumer demanding those rights, but rather an active one of a civic duty to financially support the system relied upon in times of sickness, yet with little control over the services provided. The pre-NHS citizen patient was therefore not so much a citizen-consumer or a welfare citizen as a citizen-contributor.

\section{The social meaning of payment}

To make sense of the fact that payment in Britain's pre-NHS hospitals brought about a new brand of citizen-contributor rather than empowered consumers, it is useful to briefly examine what has been said about the social function of money beyond the writings of historians. A longstanding and influential utilitarian notion about money is what Thomas Carlyle termed the 'cash nexus', according to which economic concerns and ties replace all others - social, cultural or moral. Following this line of thinking, Anthony Giddens described the dominance of money over social context as one of the disembedding mechanisms so crucial to 
modernity ${ }^{108}$ This view of money as a language that could communicate value, but was silent on values, has been challenged since the 1980s by scholars associated with the new economic sociology, such as Mark Granovetter and Viviana Zelizer. ${ }^{109}$ Granovetter critiqued the treatment of people as atomised actors, even if acting according to internalised rules of behaviour, and called instead for a far greater focus on the immediate social context. ${ }^{110}$ Especially significant here is Zelizer's work on 'earmarking', whereby 'the physical homogeneity of modern currency' obscures the 'different networks of social relations and systems of meaning' which served as 'invisible boundaries' to 'mark modern money, introducing controls, restrictions, and distinctions'. The consequent qualitative differences she identifies in the various payments found in everyday modern life - distinguishing 'a tribute from a donation, a wage from an honorarium, or an allowance from a salary' - remind us of the importance of adequately questioning how to categorise the monies that made their way from patients to hospitals. ${ }^{111}$

Yet these refinements in sociological thinking about money have made surprisingly little impact on historical study, even as historians present findings that resonate strongly with such ideas in works on topics ranging from the sale of slaves to the establishment of commercial trading networks. ${ }^{112}$ Anne Digby did briefly consider payment as a form of social interaction, when she examined the 'financial dimension' that 'loomed large' in the historic relationship between a general practitioner and their patient before the NHS. ${ }^{113}$ She found practices such as retrospective billing on 'the doctor's individual assessment' to place the physician in a position of great power, far from liberating the patientconsumer. Yet, at the same time, she noted that the British medical profession refrained from an American-style 'medical entrepreneurship' in the eighteenth and nineteenth centuries, something she attributed to 'professional custom and the prevailing gentlemanly ethic."114

Despite such insights, it is those older utilitarian ideas about money that have unwittingly underpinned historians' limited considerations of the arrival of patient payment schemes in British hospitals in the early twentieth century. It has been assumed that, once money enters the relationship between individual and institution, existing values - those commonly associated with Victorian philanthropy - were swept away. The broadening of the patient base and the purchasing power of the patients themselves are assumed to have flattened the distinctions 
between classes and disentangled the delivery of medical treatment from a wider system of social interaction and even social control. The persistent assumption has been that the decades preceding the establishment of the NHS saw philanthropy neutralised within the arena of the hospital. As the following chapters will make clear, this simply did not happen.

\section{Conclusion}

The shift to patients paying the hospital has long been a feature, even if a rather minor one, of histories of modern healthcare. In the British case, it has served as an example of both what was wrong and what was already changing before the creation of the NHS in 1948. It has likewise been used as evidence in assessments of the ultimate success or failure of the pre-NHS hospital system. Only rarely, however, has it been considered on its own terms: as a pragmatic yet far-reaching change to the patient contract within a wider reconfiguration of the social function of the hospital. The following chapters will seek to address this, examining the workings, scale and meanings of paying the hospital in Britain during those final decades before the establishment of the NHS.

To do so, it is crucial to understand two defining characteristics of the pre-NHS hospital. First, for those institutions dominating the delivery of acute medical care, the hospital was a charity. The patient was not a medical consumer but a recipient of medical charity. This coloured the economic encounter that was brought about by the introduction of patient payments, setting a course not so much towards consumer empowerment as civic contribution. Second, whether in the voluntary or public sector, the hospital was a local institution. Although hospitals across the country showed remarkable consistency in the introduction of patient payments, decisions were taken at the local, municipal or institutional level. As such, the next chapter turns to our case study city, surveying the hospitals of Bristol and placing them firmly within a local economic, political and social context.

\section{Notes}

1 Birmingham Post, 7 January 1938.

2 Martin Gorsky, 'The Political Economy of Health Care in the Nineteenth and Twentieth Centuries' in Mark Jackson (ed.), The Oxford Handbook 
of the History of Medicine (Oxford: Oxford University Press, 2011), p. 437.

3 Timothy B. Smith, Creating the Welfare State in France, 1880-1940 (Montreal: McGill-Queen's University Press, 2003), p. 134.

4 Charles Rosenberg, The Care of Strangers: The Rise of America's Hospital System (New York: Johns Hopkins University Press, 1987), pp. 237-8.

5 Key texts on this period of British politics include Paul Addison, The Road to 1945: British Politics and the Second World War, revised edition (London: Pimlico, 1994); Harold Smith, War and Social Change: British Society in the Second World War (Manchester: Manchester University Press, 1986); Arthur Marwick, Britain in the Century of Total War: War, Peace and Social Change, 1900-1967 (Harmondsworth: Penguin, 1970); David Kynaston, Austerity Britain 1945-48: A World to Build (London: Bloomsbury, 2007); Andrew Thorpe, Parties at War: Political Organisation in Second World War Britain (Oxford: Oxford University Press, 2009).

6 For rather different assessments of the 1945 Labour administration, see Kevin Jeffreys, The Attlee Governments 1945-1951 (London: Longman, 1992); Correlli Barnett, Barnett, The Lost Victory: British Dreams, British Realities, 1945-1950 (London: Pan Books, 1996).

7 For the wider literature on the 1945 election and Attlee's government see Addison, Road to 1945; Jim Tomlinson, Democratic Socialism and Economic Policy: The Attlee Years, 1945-1951 (Cambridge: Cambridge University Press, 2002); Kenneth O. Morgan, The People's Peace: British History 1945-1989 (Oxford: Oxford University Press, 1990), pp. 1-111.

8 See, for example, Rodney Lowe, The Welfare State in Britain since 1945, 3rd edition (London: Palgrave Macmillan, 2004); Nicholas Timmins, The Five Giants: A Biography of the Welfare State, Revised Edition (London: Harper Collins, 2001), pp. 101-39.

9 Geoffrey Rivett, From Cradle to Grave: Fifty Years of the NHS (London: King's Fund, 1997), pp. 30-1.

10 Charles Webster, The Health Services since the War, Volume 1: Problems of Health Care, The National Health Service Before 1957 (London: HMSO, 1988), pp. 390-3; Charles Webster, The National Health Service: A Political History, 2nd revised edition (Oxford: Oxford University Press, 2002), p. 255. See also Charles Webster, 'Birth of a Dream: Bevan and the Architecture of the National Health Service' in Geoffrey Goodman (ed.), The State of the Nation: The Political Legacy of Aneurin Bevan (London: Victor Gollancz, 1997), pp. 106-27; Richard Titmuss, Problems of Social Policy (London: HMSO, 1950); Brian Abel-Smith, The Hospitals 1800-1948 (London: Heinemann, 1964); Robert Pinker, English Hospital Statistics 1861-1938 (London: Heinemann, 1966). 
11 Webster, Health Services, p. 399. See also John Pater, The Making of the National Health Service (London: King's Fund, 1981), pp. 105-38.

12 See John Stewart, "For a Healthy London”: The Socialist Medical Association and the London County Council in the 1930s', Medical History, 42:4 (1997), 417-36; John Stewart, The Battle for Health': A Political History of the Socialist Medical Association, 1930-51 (Aldershot: Ashgate, 1999); John Stewart, 'Ideology and Process in the Creation of the British National Health Service', Journal of Policy History, 14:1 (2002), 113-34.

13 Bristol and District Divisional Hospitals Council, Report for 1944, p. 3.

14 Webster, Health Services, pp. 22-3; John Mohan, Planning, Markets and Hospitals (London: Routledge, 2002), p. 10; Geoffrey Rivett, The Development of the London Hospital System, 1823-1982 (London: King's Fund, 1982), http://www.nhshistory.net/Londonshospitals.htm, chapter on 'Emergency Medical Services, 1939-1948', accessed 25 April 2016. However, some of this narrative is called into question by the reassessment of public attitudes towards 1940s health reform in Nick Hayes, 'Did We Really Want a National Health Service? Hospitals, Patients and Public Opinions before 1948, English Historical Review, 128:526 (2012), 625-61.

15 See for example Martin Gorsky, “"Threshold of a New Era”: The Development of an Integrated Hospital System in Northeast Scotland, 1900-1939', Social History of Medicine, 17:2 (2004), 247-67; Barry M. Doyle, 'Competition and Cooperation in Hospital Provision in Middlesbrough, 19181948', Medical History, 51:3 (2007), 337-56.

16 John Stewart, "“The Finest Municipal Hospital Service in the World”? Contemporary Perceptions of the London County Council's Hospital Provision, 1929-1939', Urban History, 32:2 (2005), 327-44.

17 Martin Powell, 'An Expanding Service: Municipal Acute Medicine in the 1930s', Twentieth Century British History, 8:3 (1997), 334-57; Alysa Levene, 'Between Less Eligibility and the NHS: The Changing Place of Poor Law Hospitals in England and Wales, 1929-39', Twentieth Century British History, 20:3 (1997), 322-45.

18 Pat Thane, Foundations of the Welfare State, 2nd edition (Harlow: Longman, 1996), p. 277. See also Martin Daunton, 'Introduction' in Martin Daunton (ed.) Charity, Self-Interest and Welfare in the English Past (London: UCL Press, 1996), p. 1; Addison, Road to 1945. For a clear and concise introduction to approaching the history of welfare in this way, see John Stewart, 'The Mixed Economy of Welfare in Historical Context' in Martin Powell (ed.), Understanding the Mixed Economy of Welfare (Bristol: Policy Press, 2007), pp. 23-40. 
19 Beyond the voluntary hospitals, see for example Linda Bryder, 'The King Edward VII Welsh National Memorial Association and Its Policy towards Tuberculosis, 19010-1948', Welsh History Review, 13:2 (1986), 194-216; F.K. Prochaska, Philanthropy and the Hospitals of London: The King's Fund, 1897-1990 (Oxford: Clarendon Press, 1992).

20 Barry M. Doyle, 'Author's Response to Review of "The Politics of Hospital Provision in Early Twentieth-Century Britain"', Reviews in History, review no. 1733 (February 2015), www.history.ac.uk/reviews/review/1733, accessed 25 April 2016.

21 Keir Waddington, 'Paying for the Sick Poor: Financing Medicine under the Victorian Poor Law: The Case of the Whitechapel Union, 1850-1900', in Martin Gorsky and Sally Sheard (eds), Financing Medicine: The British Experience since 1750 (London: Routledge, 2006), pp. 100-1.

22 Paul Weindling, 'Introduction' in Paul Weindling (ed.), Healthcare in Private and Public from the Early Modern Period to 2000 (London: Routledge, 2015), p. 3.

23 Martin Gorsky, "For the Treatment of Sick Persons of All Classes": The Transformation of Bristol's Hospital Services, 1918-1939' in Peter Wardley (ed.), Bristol Historical Resource, CD-ROM (Bristol: University of the West of England, 2001).

24 John Pickstone, Medicine and Industrial Society: A History of Hospital Development in Manchester and Its Region (Manchester: Manchester University Press, 1985), p. 272.

25 Titmuss, Problems of Social Policy, pp. 66-7.

26 David Hamilton, 'The Highlands and Islands Medical Service' in Gordon McLachlan (ed.), Improving the Common Weal: Aspects of Scottish Health Services 1900-1984 (Edinburgh: Edinburgh University Press, 1987), p. 483.

27 Tim Willis, 'The Bradford Municipal Hospital Experiment of 1920: The Emergence of the Mixed Economy in Hospital Provision in Inter-War Britain' in Gorsky and Sheard (eds), Financing Medicine, pp. 130-44.

28 Stewart, 'Finest Municipal Hospital Service'.

29 Political and Economic Planning, 'Report on the British Health Services' (London: PEP, 1937), p. 17.

30 Gorsky, 'Threshold of a New Era', pp. 249 and 265.

31 Martin Gorsky, 'The Gloucestershire Extension of Medical Services Scheme: An Experiment in the Integration of Health Services in Britain before the NHS', Medical History, 50:4 (2006), 510.

32 Alysa Levene, Martin Powell, John Stewart and Becky Taylor, From Cradle to Grave: Municipal Provision in Interwar England and Wales (Bern: Peter Lang, 2011). 
33 Barry Doyle, 'Power and Accountability in the Voluntary Hospitals of Middlesbrough 1900-48' in Peter Shapely and Anne Borsay (eds), Medicine, Charity and Mutual Aid: The Consumption of Health and Welfare, c.1550-1950 (Aldershot: Ashgate, 2006), pp. 207-24; Barry M. Doyle, The Politics of Hospital Provision in Early 20th-Century Britain (London: Pickering and Chatto, 2014).

34 Charles Webster, 'Conflict and Consensus: Explaining the British Health Service', Twentieth Century British History, 1:2 (1990), 115-51.

35 Roy Porter, 'The Gift Relation: Philanthropy and Provincial Hospitals in Eighteenth-Century England' in Lindsay Granshaw and Roy Porter (eds), The Hospital in History (London: Routledge, 1989), pp. 150-2. On the early history of the voluntary hospitals, see John Woodward, To Do the Sick No Harm: A Study of the British Voluntary Hospital System to 1875 (London: Routledge and Kegan Paul, 1974).

36 Lindsay Granshaw, " "Fame and Fortune by Means of Bricks and Mortar”: The Medical Profession and Specialist Hospitals in Britain, 1800-1948' in Granshaw and Porter (eds), Hospital in History, pp. 199-220.

37 Hilary Marland, 'Lay and Medical Conceptions of Medical Charity during the Nineteenth Century' in Jonathan Barry and Colin Jones (eds), Medicine and Charity before the Welfare State (London: Routledge, 1991), pp. 149-71.

38 Jonathan Reinarz, 'Investigating the "deserving" Poor: Charity, Discipline and Voluntary Hospitals in Nineteenth-Century Birmingham' in Shapely and Borsay (eds), Medicine, Charity and Mutual Aid, pp. 111-33; Martin Gorsky, John Mohan, and Martin Powell, 'British Voluntary Hospitals 1871-1939: The Geography of Provision and Utilization', Journal of Historical Geography, 25:4 (1999), 476.

39 Keir Waddington, "'Grasping Gratitude”: Charity and Hospital Finance in Late-Victorian London' in Daunton (ed.), Charity, Self-Interest, pp. 181-202.

40 Jonathan Reinarz, 'Charitable Bodies: The Funding of Birmingham's Voluntary Hospitals in the Nineteenth Century' in Gorsky and Sheard (eds), Financing Medicine, pp. 40-58.

41 Martin Gorsky, John Mohan and Martin Powell, 'The Financial Health of Voluntary Hospitals in Interwar Britain', Economic History Review, 55:3 (2002), 549-50.

42 Martin Gorsky and Sally Sheard, 'Introduction' in Gorsky and Sheard (eds), Financing Medicine, pp. 9-10.

43 Powell, 'An Expanding Service'; George Campbell Gosling and Stephen Soanes, 'Healthcare and the Community in Modern Britain', Family and Community History, 12:2 (2009), 101-6. 
44 For an extensive discussion, see Levene et al., Cradle to Grave.

45 Martin Daunton, 'Payment and Participation: Welfare and State-Formation in Britain, 1990-1951', Past and Present, 150 (1990), 188-91.

46 Steven Cherry, 'Before the National Health Service: Financing the Voluntary Hospitals, 1900-1939', Economic History Review, 50:2 (1997), 305-26.

47 Nick Hayes and Barry M. Doyle, 'Eggs, Rags and Whist Drives: Popular Munificence and the Development of Provincial Medical Voluntarism between the Wars', Historical Research, 86:234 (2013), 714.

48 Ibid., 734-7.

49 Doyle, Politics of Hospital Provision, p. 136.

50 Nick Hayes, "'Our Hospitals"? Voluntary Provision, Community and Civic Consciousness in Nottingham Before the NHS', Midland History, 37:1 (2012), 100.

51 See Alysa Levene, Martin Powell, and John Stewart, 'Patterns of Municipal Health Expenditure in Interwar England and Wales', Bulletin of the History of Medicine, 78:3 (2004), 644-6.

52 For a good introduction to the changing social function of the hospital, see Hilary Marland, 'The Changing Role of the Hospital, 1800-1900' in Deborah Brunton (ed.), Medicine Transformed: Health, Disease and Society in Europe 1800-1930 (Manchester: Manchester University Press, 2004), pp. 31-60.

53 On the long history of the hospital see, for example, Guenter Risse, Mending Bodies, Saving Souls: A History of Hospitals (Oxford: Oxford University Press, 1999).

54 Paul Starr, The Social Transformation of American Medicine (New York: Basic Books, 1982), p. 145.

55 On the patient narrative see, for example, Mary Fissell, 'The Disappearance of the Patient Narrative and the Invention of Hospital Medicine' in Roger French and Andrew Wear (eds), British Medicine in an Age of Reform (London: Routledge, 2002), pp. 92-109. On 'de-personalisation' see Reinarz, 'Investigating the Deserving Poor'; Reinarz, 'Charitable Bodies'.

56 Gorsky, 'Political Economy', p. 435.

57 Marland, 'Changing Role of the Hospital', p. 58.

58 Steven Cherry, 'Beyond National Health Insurance. The Voluntary Hospitals and Hospital Contributory Schemes: A Regional Study', Social History of Medicine, 5:3 (1992), 455-82.

59 Starr, Social Transformation, p. 171.

60 Rosenberg, Care of Strangers, pp. 237-8.

61 James Monahan, Bear Ye One Another's Burdens: The Growth of Rockford Memorial Hospital, 1900-1983 (Rockford, Illinois, 1985), p. 10. 
62 Austin History Center, H2700 (1): Brackenridge Hospital, History and Description (folder 2), The Good Life in Austin: A Brief History of Brackenridge Hospital (loose pages).

63 Starr, Social Transformation, p. 159.

64 Ibid., p. 165.

65 Ibid., p. 154.

66 Ibid., p. 157.

67 Rosenberg, Care of Strangers, p. 237.

68 David Rosner, A Once Charitable Enterprise: Hospitals and Health Care in Brooklyn and New York, 1885-1915 (Cambridge: Cambridge University Press, 1982), pp. 138-49.

69 Rosenberg, Care of Strangers, p. 161.

70 Starr, Social Transformation, p. 148.

71 Rosenberg, Care of Strangers, p. 253. For the general discussion on this point see pp. 252-8.

72 Richard Freeman, The Politics of Health in Europe (Manchester: Manchester University Press, 2000), pp. 14-23.

73 Jean-Paul Domin, Une Histoire Economique de l'Hôpital (XIXe-XXeSiècles): Une Analyse Rétrospective du Développement Hospitalier, 2 vols (Paris: La Documentation Française, 2008) cited in Barry M. Doyle, 'Healthcare before Welfare States: Hospitals in Early Twentieth Century England and France', Canadian Bulletin of Medical History, 33:1 (2016), 174-204.

74 Timothy B. Smith, Creating the Welfare State in France, 1880-1940 (Montreal: McGill-Queen's University Press, 2003), pp. 3 and 115.

75 For an overview of the French hospital system and comparison with the British, see Doyle, 'Healthcare before Welfare States'.

76 Smith, Creating the Welfare State, pp. 94-5.

77 Ibid., pp. 98-9; Gorsky, 'Political Economy', p. 437.

78 Smith, Creating the Welfare State, pp. 132-4.

79 Ibid., pp. 125-30.

80 Ibid., p. 128.

81 Ibid., p. 153.

82 Ibid., p. 154.

83 Ibid., pp. 129 and 152.

84 Doyle, 'Healthcare before Welfare States'.

85 Henry Burdett, Pay Hospitals and Paying Wards throughout the World: Facts in Support of a Re-Arrangement of the English System of Medical Relief (London: J.\&A. Churchill, 1879), p. 93.

86 For an introduction to the various healthcare services operating in Ireland historically, see Ruth Barrington, Health, Medicine and Politics in Ireland, 1900-1970 (Institute of Public Administration: Dublin, 1987). 
87 Donnacha Seán Lucey and George Campbell Gosling, 'Paying for Health: Comparative Perspectives on Patient Payment and Contributions for Hospital Provision in Ireland' in Donnacha Seán Lucey and Virginia Crossman (eds), Healthcare in Ireland and Britain from 1850: Voluntary, Regional and Comparative Perspectives (London: Institute of Historical Research, 2015), pp. 81-92.

88 Hospitals Year-Books (London: Central Bureau of Hospital Information [hereafter CBHI], 1933-1947).

89 Hospital Commission, First General Report, 1933-34 (Dublin, 1936), p. 68.

90 Ibid., pp. 16 and 122.

91 Lucey and Gosling, 'Paying for Health', p. 94.

92 Marie Coleman, The Irish Sweep: A History of the Irish Hospitals Sweepstakes, 1930-87 (Dublin: University College Dublin Press, 2009).

93 Hospital Commission, First Report, p. 69.

94 Ibid.

95 Hospitals Year-Book (London: CBHI, 1933).

96 See Lucey and Gosling, 'Paying for Health', pp. 92-9.

97 Hilary Marland, Medicine and Society in Wakefield and Huddersfield, 17801870 (Cambridge: Cambridge University Press, 1987); R.J. Morris, Class, Sect and Party. The Making of the British Middle Class: Leeds, 1820-50 (Manchester: Manchester University Press, 1990); Martin Gorsky, Patterns of Philanthropy: Charity and Society in Nineteenth-Century Bristol (Woodbridge: Boydell \& Brewer Ltd, 1999).

98 Mary Fissell, Patients, Power, and the Poor in Eighteenth-Century Bristol (Cambridge: Cambridge University Press, 1991); Gorsky, Patterns of Philanthropy.

99 Gorsky and Sheard, 'Introduction', p. 2.

100 Abel-Smith, Hospitals, p. 338; Pickstone, Medicine and Industrial Society, p. 259.

101 For work that does focus on the continuing importance of traditional sources of philanthropic income, see Hayes and Doyle, 'Eggs, Rags and Whist Drives'.

102 See Alan Kidd, 'Philanthropy and the "Social History Paradigm", Social History, 2:2 (1996), 180. See also Marcel Mauss, The Gift (London: Routledge, 1990) [originally published 1950].

103 Fernand Braudel, The Mediterranean and the Mediterranean World in the Age of Philip II, Volume 2, 1996 edition (Berkeley: University of California Press, 1949), p. 826.

104 Michel Foucault, The Birth of the Clinic: An Archaeology of Medical Perception (London: Tavistock Publications, 1973). 
105 Gorsky, 'Transformation of Bristol's Hospital Services'.

106 Steven Thompson, 'A Proletarian Public Sphere: Working-Class Provision of Medical Services and Care in South Wales, c.1900-1948' in Anne Borsay (ed.), Medicine in Wales c.1800-2000: Public Service or Private Commodity? (Cardiff: University of Wales Press, 2003), p. 87.

107 Doyle, 'Politics of Voluntary Care'; Barry M. Doyle, 'Labour and Hospitals in Three Yorkshire Towns: Middlesbrough, Leeds, Sheffield, 19191938', Social History of Medicine, 23:2 (2010), 374-92.

108 Anthony Giddens, The Consequences of Modernity (Stanford: Stanford University Press, 1990), pp. 21-5.

109 See Geoffrey Ingham, The Nature of Money (Cambridge: Polity, 2004), especially ch. 3: 'Money in Sociological Theory'.

110 Mark Granovetter, 'Economic Action and Social Structure: The Problem of Embeddedness', American Journal of Sociology, 91:3 (1985), 482.

111 On 'earmarking' see Viviana A. Zelizer, The Social Meaning of Money: Pin Money, Paychecks, Poor Relief, and Other Currencies (New York: Princeton University Press, 1994), pp. 21-5.

112 See, for example, Dea Boster, African American Slavery and Disability: Bodies, Property and Power in the Antebellum South, 1800-1860 (London: Routledge, 2013) and Sheryllynne Haggerty, 'Merely for Money'? Business Culture in the British Atlantic, 1750-1815 (Liverpool: Liverpool University Press, 2012).

113 Anne Digby, The Evolution of British General Practice, 1850-1948 (Oxford: Oxford University Press, 1999), p. 242.

114 Ibid., p. 94; Anne Digby, Making a Medical Living: Doctors and Patients in the English Market for Medicine, 1720-1911 (Cambridge: Cambridge University Press, 1994), p. 135. 